\title{
LABORATORY EXPERIMENTAL ANALYSIS ON ENCAPSULATED STONE COLUMN
}

\author{
Y.K. TANDEL ${ }^{1}$, C.H. SOLANKI ${ }^{2}$, A.K. DESAI ${ }^{3}$
}

\begin{abstract}
The application of stone column technique for improvement of soft soils has attracted a considerable attention during the last decade. However, in a very soft soil, the stone columns undergo excessive bulging, because of very low lateral confinement pressure provided by the surrounding soil. The performance of stone column can be improved by the encapsulation of stone column by geosynthetic, which acts to provide additional confinement to columns, preventing excessive bulging and column failure. In the present study, a detailed experimental study on behavior of single column is carried out by varying parameters like diameter of the stone column, length of stone column, length of geosynthetic encapsulation and stiffness of encapsulation material. In addition, finite-element analyses have been performed to access the radial deformation of stone column. The results indicate a remarkable increase in load carrying capacity due to encapsulation. The load carrying capacity of column depends very much upon the diameter of the stone column and stiffness of encapsulation material. The results show that partial encapsulation over top half of the column and fully encapsulated floating column of half the length of clay bed thickness give lower load carrying capacity than fully encapsulated end bearing column. In addition, radial deformation of stone column decreases with increasing stiffness of encapsulation material.
\end{abstract}

Keywords: Stone column, Encapsulation, Geosynthetic, Experiment, FEM, Load carrying capacity, Radial deformation, Deformed shape.

\section{INTRODUCTION}

Ordinary stone columns are generally suited for soft soils with undrained cohesion more than about $15 \mathrm{kPa}$ (ALEXIEW et al. [1]), as the confining pressure provided by soil surrounding the column may be insufficient to prevent excessive bulging of column. Recently, the use of stone column has been extended to extremely soft soils using geosynthetic encasement to provide additional confinement.

KEMPFERT and WALLIS [2] reported the first application of geosynthetic encapsulated stone column for widening an about $5 \mathrm{~m}$ high railroad embankment on peat and clay soils in Hamburg. Case histories on the use of this technique to improve soft soil are reported by KEMPFERT et al. [3], TRUNK et al. [4], DE MELLO et al. [5], Araujo et al. [6], etc.

1 Corresponding Author. Applied Mechanics Department, S. V. National Institute of Technology, Surat-395007, India, tandel.yogendra@gmail.com

2,3 Applied Mechanics Department, S. V. National Institute of Technology, Surat-395007, India, chs@ amd.svnit.ac.in,akd@amd.svnit.ac.in 
Laboratory model tests on geosynthetic-encapsulated stone columns have been performed by AYADAT and HANNA [7], DI PRISCO [8], MALARVIZHI and ILLAMPARUTHI [9], MURUGESAN and RAJAGOPAL [10], GNIEL and BOUAZZA [11], WU and HONG [12], etc.

Numerical studies on geosynthetic encapsulated stone columns have been carried out by KHABBAZIAN et al. [13], LO et al. [14], MURUGESAN and RAJAGOPAL [15], PULKO et al. [16], YOO and KIM [17] and ZHANG et al. [18], RAITHEL and KEMPFERT [19], WU et al. [20], among others.

Most of the laboratory work done is limited to fully encapsulated end bearing column, and very little information is available on the floating columns and partially encapsulated column. In the present study, an extensive parametric study was carried out to understand the influence of diameter of the stone column, stiffness of the encapsulation material, length of column and encapsulation length on load-deformation behaviour of stone column.

\section{General feAtures}

\subsection{TESTING MODEL}

A schematic view of model stone column is shown in Fig. 1. The model tests were performed in steel cylindrical tanks of $260 \mathrm{~mm}$ diameter, $600 \mathrm{~mm}$ height. The depth of clayey bed was $450 \mathrm{~mm}$. All tests were performed at a constant room temperature. The column diameters used in the model tests are 50 and $75 \mathrm{~mm}$.

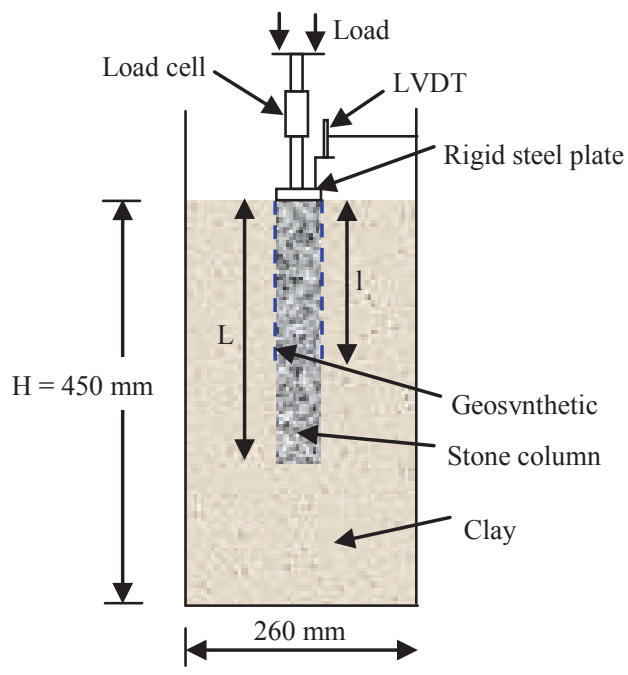

Fig. 1. Schematic diagram of model test. 


\subsection{DESCRIPTION OF MATERIALS}

\subsubsection{Clay}

The clay used is of CL classification collected at a depth of $2 \mathrm{~m}$. Sample collected was air-dried and pulverized. The pulverized sample was sieved through $2 \mathrm{~mm}$ sieve for easy mixing and quicker hydration. Typical particle size distribution is shown in Fig. 2. The undrained shear strength $\mathrm{C}_{\mathrm{u}}$ of the soft soil bed was obtained by conducting vane shear tests. Modulus of elasticity of the clay reported is the secant moduli determined from triaxial compression test at low confining pressure prevail in the model tests. The Poisson's ratio used is as per typical values suggested by BOWLES [21].

Table 1

Properties of clay bed

\begin{tabular}{|c|c|}
\hline Property & Value \\
\hline Liquid limit (\%) & 46 \\
\hline Plastic limit (\%) & 17 \\
\hline Plasticity Index (\%) & 29 \\
\hline Specific gravity & 2.56 \\
\hline Unified soil classification & $\mathrm{CL}$ \\
\hline Dry unit weight $\left(\mathrm{kN} / \mathrm{m}^{3}\right)$ & 12.50 \\
\hline Bulk unit weight $\left(\mathrm{kN} / \mathrm{m}^{3}\right)$ & 17 \\
\hline Undrained cohesion $(\mathrm{kPa})$ & $8-10$ \\
\hline Modulus of elasticity $(\mathrm{kPa})$ & 106 \\
\hline Poisson ratio & 0.49 \\
\hline
\end{tabular}



Fig. 2. Particle size distribution of clay and sand. 


\subsubsection{Sand}

River sand passing from $4.75 \mathrm{~mm}$ were used for model columns. Particle size distribution of sand is shown in Fig. 2. The angle of internal friction and the dilation angle reported in Table 2 are based on direct shear test. Poisson's ratio reported is as per BOWLES [21]. The sand is compacted to a density of $1.6 \mathrm{~g} / \mathrm{cm}^{3}$. Other properties of the sand for the stone column are given in Table 2. The modulus was obtained from drained triaxial test at low confining pressure.

Table 2

Properties of sand

\begin{tabular}{|c|c|}
\hline Property & Value \\
\hline Specific gravity & 2.76 \\
\hline Dry unit weight $\left(\mathrm{kN} / \mathrm{m}^{3}\right)$ & 16 \\
\hline Angle of internal friction $(\mathrm{deg})$ & 30 \\
\hline Dilatancy angle $(\mathrm{deg})$ & 0 \\
\hline Uniformity coefficient & 3.56 \\
\hline Coefficient of curvature & 0.72 \\
\hline Modulus of elasticity $(\mathrm{kPa})$ & 1886 \\
\hline Poisson ratio & 0.30 \\
\hline
\end{tabular}

\subsubsection{Geosynthetic}

Three different types of geosynthetic were used to encapsulate the stone columns in the present study, which are (i) Nova curtain (Net), commercially known as mosquito net, (ii) Non-woven geotextile and (iii) Woven geotextile. Geotextile in the form of tube was made by bonding the section with epoxy-resin. The load deformation behaviour observed from standard wide-width tension tests (ASTM D4595 [22]) on different geosynthetics is shown in Fig. 3.

\section{Testing PROCEDURE}

\subsection{Clay bed preparation}

In all the tests, the clay bed was prepared with shear strength of $9 \mathrm{kPa}$ by a moulding procedure. The required quantity of water $(=36 \%)$ determined by trial and error, was added to clay. The bulk unit weight at $36 \%$ water content was found as $17 \mathrm{kN} / \mathrm{m}^{3}$. Initially the soil was thoroughly mixed with the water and kept covered with a wet jute 


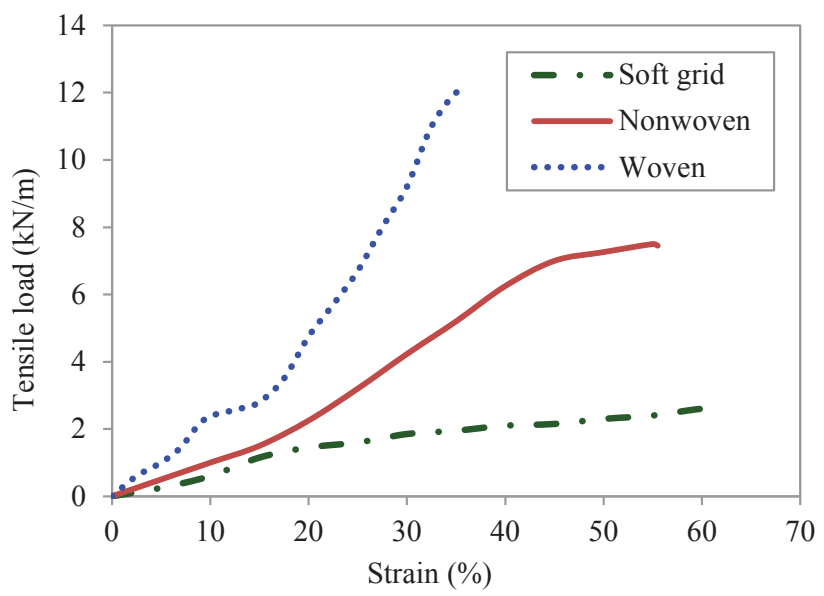

Fig. 3. Tensile load-strain behaviour of different geosynthetics.

fabric for 48 hours in order to achieve uniform consistency. After 48 hours of hydration, the soil was mixed and kneaded well and checked for moisture content. Loss of water, if any due to evaporation was compensated by adding water before forming the bed. A thin coat of grease was applied along the inner surface of tank wall to reduce friction between clay and tank wall. Clay was filled in the tank in layers with measured quantity by weight. The surface of each layer was provided with uniform compaction with a tamper to achieve a $50 \mathrm{~mm}$ height and uniform density as per requirement. Care was taken to ensure that no significant air voids were left out in the test bed.

\subsection{Column installation}

A stone column of the required diameter was installed at the centre of the tank. All the columns were installed by the displacement method. A casing pipe (closed at the bottom with base plate) with an outer diameter equal to the diameter of the column was used to install the stone columns. For ordinary stone column, casing pipe was pushed into the soil along with a base plate having a circular groove to accommodate the casing pipe in order to prevent the soil from entering the pipe during the installation. When the casing pipe is pulled out, the base plate remains in the soil. In the case of reinforced sand columns, the reinforcement was provided around the casing pipe, which also covers the base plate. The quantity of the sand aggregate required to form the sand column was pre-measured and charged into the casing pipe in layers $50 \mathrm{~mm}$ thickness. The pipe was then raised in stages ensuring a minimum of $10 \mathrm{~mm}$ penetration below the top level of the placed sand. For a column to achieve a uniform density, compaction was given with a $1.3 \mathrm{~kg}$ circular steel tamper with 12 blows of $150 \mathrm{~mm}$ drop to each layer. This light compaction effort was adopted to ensure that there is no significant lateral bulging of 
the column creating disturbance to the surrounding soft clay. The corresponding density was found to be $1.6 \mathrm{~g} / \mathrm{cm}^{3}$ for stone column. The procedure was repeated until the column is completed to the full height.

In case of encapsulated stone column, casing pipe along with geosynthetic reinforcement wrapped around the casing pipe \& base plate was slowly pushed into the clay bed, vertically and concentrically in the tank, until it reached the bottom of the tank. Static force was used to push the casing pipe into the soil so as to minimize the disturbance in the clay soil. The clay displaced during the installation was taken out, and the surface of the soil was trimmed and levelled. When the casing pipe is pulled out, the geosynthetic reinforces the sand column.

\subsection{LOAD APPLICATION}

After forming the stone column, vertical load was applied at a constant strain rate of $1.25 \mathrm{~mm} / \mathrm{min}$ through a rigid loading plate with diameter equal to that of the stone column, placed over the stone column to assess the enhancement in load carrying capacity due to the encapsulation. The loads corresponding to different displacements were measured using a load cell (having an accuracy of $0.01 \mathrm{kN}$ ). The deformation was measured using a LVDT (Linear Variable Displacement Transducer) having an accuracy of $0.01 \mathrm{~mm}$ (Fig. 4). Since the loading is rapid, it is essentially undrained loading, which simulates loading immediately after construction. Tests are continued upto vertical settlement of $50 \mathrm{~mm}$.

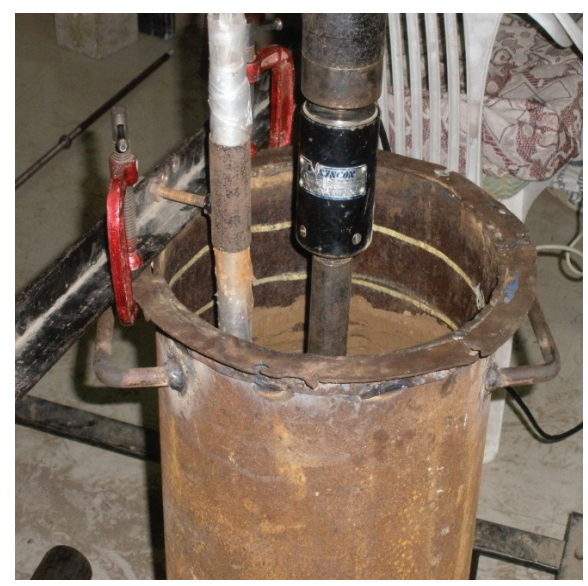

(a) Experimental set up

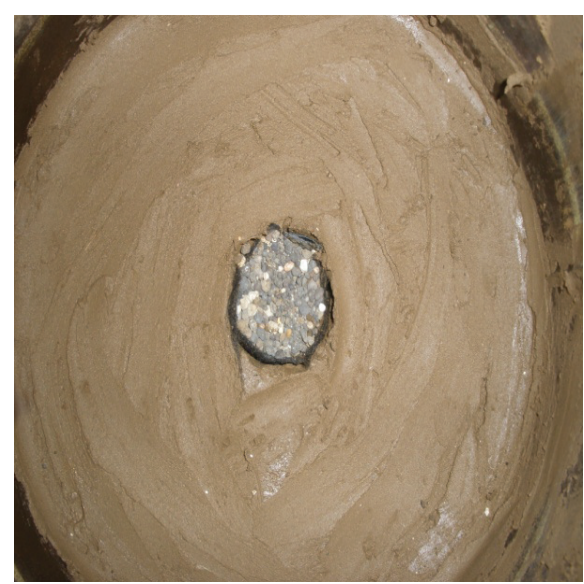

(b) Installed column

Fig. 4. Experimental model set up. 


\subsection{FEM MODELLING}

For finite-element analyses of the laboratory model tests, three dimensional finiteelement models of exactly the same size as the laboratory models were prepared and analyzed using PLAXIS 3D software (BRINKGREVE and VERMEER [23]). Roller supports were used on the vertical faces of the clay bed. The bottom face of the clay bed was considered as fixed.

Mohr-coulomb failure criterion was adopted for stone columns and clay having linearly elastic perfectly plastic behaviour. The geosynthetic was modeled as geogrid element available in PLAXIS 3D having axial stiffness only. The input parameters for clay and sand $(C, E, \phi, \mu, \psi, \gamma)$ are given in Table 1 and 2 respectively.

The zone of interface between stone column-geosynthetic and geosynthetic-clay is a zone with very high difference in magnitudes in young's modulus of the order of ten times or more. In addition, the shear strength properties of this zone depend on the method of installation of stone column. The above two properties of the interface are very difficult to quantify, and during the loading stage the stone column undergoes bulging and induce lateral displacement of clay in the radial direction, where the shearing phenomenon along the interface is nearly absent. Hence, to make the analysis simple, the interface element is not considered in the analysis. The mesh was refined in the region of the column-soil interface to increase the accuracy of the predictions. Fig. 5 shows the mesh discretization adopted for the model.

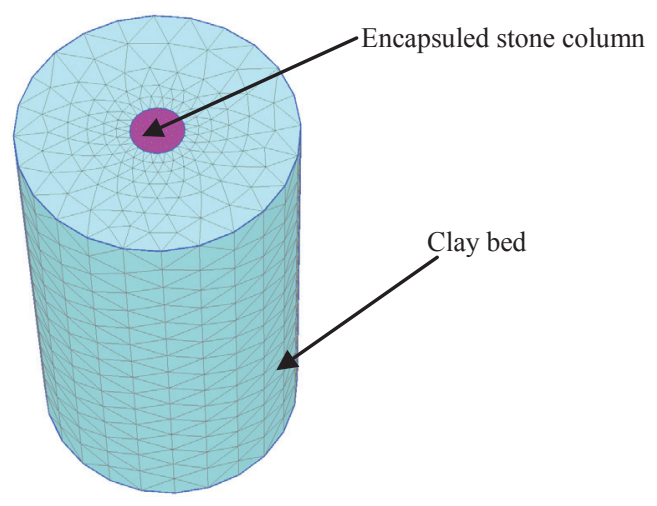

Fig. 5. Typical finite element mesh used in the analyses.

Application of this material model was verified with the published results of AMBILY and GANDHI [24] wherein Mohr Coulomb model was used to analyze the stone column and clay bed. Fig. 6 compares the results of numerical study carried out in the present study with both the experimental and the numerical results of AMBILY and GANDHI [24], which matches well. Therefore, this model was adopted for further 
analysis. MUSTAFA et al. [25] have also adopted the same constitutive model for the stone column and the soft clay bed.

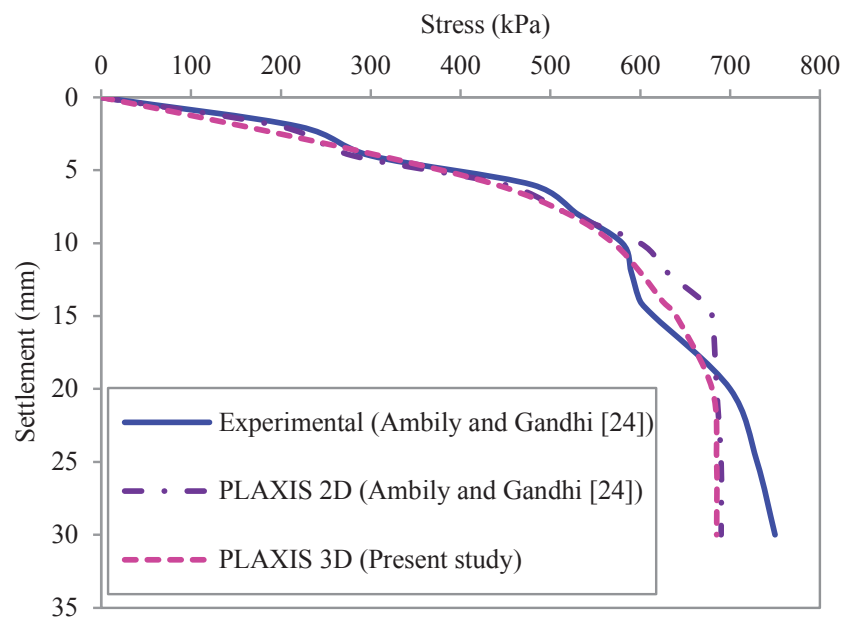

Fig. 6. Validation of FEM with Ambily and Gandhi [24].

\section{RESULTS AND DISCUSSION}

\subsection{EFFECT OF STIFFNESS OF ENCAPSULATION ON STRESS-SETTLEMENT BEHAVIOUR OF STONE COLUMN}

The stress-settlement response of end bearing stone column encapsulated using three different geosynthetic is compared with the response of clay bed and the clay bed treated with ordinary stone column is shown in Fig. 7. The load carrying capacity of the stone column increases when encapsulation is used. The loading on clay bed and Ordinary Stone Column (OSC) show clear catastrophic failure. Whereas the Encapsulated Stone Columns (ESCs) have shown elastic behaviour, and there is no remarkable failure. The ESCs behaved like flexible piles. The compression of ESCs was mainly due to the readjustment of the stone particle and elongation of the geosynthetic encapsulation. Failures of the ESCs were not observed at a settlement of $50 \mathrm{~mm}$. ESCs with woven geotextile exhibit stiffer response than ESCs with net and non-woven geotextile. This is due to higher stiffness of woven geotextile. The stress-settlement response for the three types of encasement is identical but maximum resistance is offered by woven geotextile. As the stiffness of encapsulating material increases the load carrying capacity of the stone column increases. The stress at $50 \mathrm{~mm}$ settlement of stone column encapsulated with non-woven geotextile and woven geotextile are $250 \mathrm{kPa}$ and $410 \mathrm{kPa}$ respectively. The increase in resistance is about two and four times more than the ordinary stone column respectively. 




Fig. 7. Effect of stiffness of encapsulation material on stress-settlement behaviour stone column.

\subsection{Effect of $l / L$ RATio on Stress-Settlement Behaviour of OSCs and ESC}

In order to investigate the effect of encapsulation length on stress-settlement response of stone column, model tests were performed with three different encapsulation lengths (50\%, $75 \%$ and $100 \%$ of column length). Figure 8 shows the stress-settlement response of stone column encapsulated with net and non-woven geotextile for different $l / L$ ratios. Results of laboratory tests indicated an increase in column axial stress with increasing $l / L$ ratios. Similar behaviour is also observed for stone column encapsulated with woven geotextile (see Fig. 9).

Compared to OSC, average increase in stress for column with $l / L$ ratio of $0.50,0.75$ and 1.00 for Column encapsulated with net are $65 \%, 92 \%$ and $110 \%$ respectively and that for column encapsulated with non-woven geotextile are $90 \%, 139 \%$ and $246 \%$ respectively. The load carrying capacity of encapsulated column for $l / L$ ratio of 0.75 was not change remarkable as compare to end bearing column $(l / L=1.00)$.

Stone column encapsulated with woven geotextile exhibit much higher stress as compared to net and non-woven geotextile. The stress at $50 \mathrm{~mm}$ settlement of encapsulated stone column with woven geotextile with $l / L$ ratio of 1.00 and 0.50 are $390.53 \mathrm{kPa}$ and $465.98 \mathrm{kpa}$ respectively, which are 1.81 times and 1.68 times the stress of stone column encapsulated with non-woven geotextile. Form Fig. 9, it is observed that a stone column encapsulated with non-woven and woven geotextile over a depth equal to 4.5 times the diameter of column, have 1.91 times and 3.45 times respectively more load carrying capacity than OSC. 


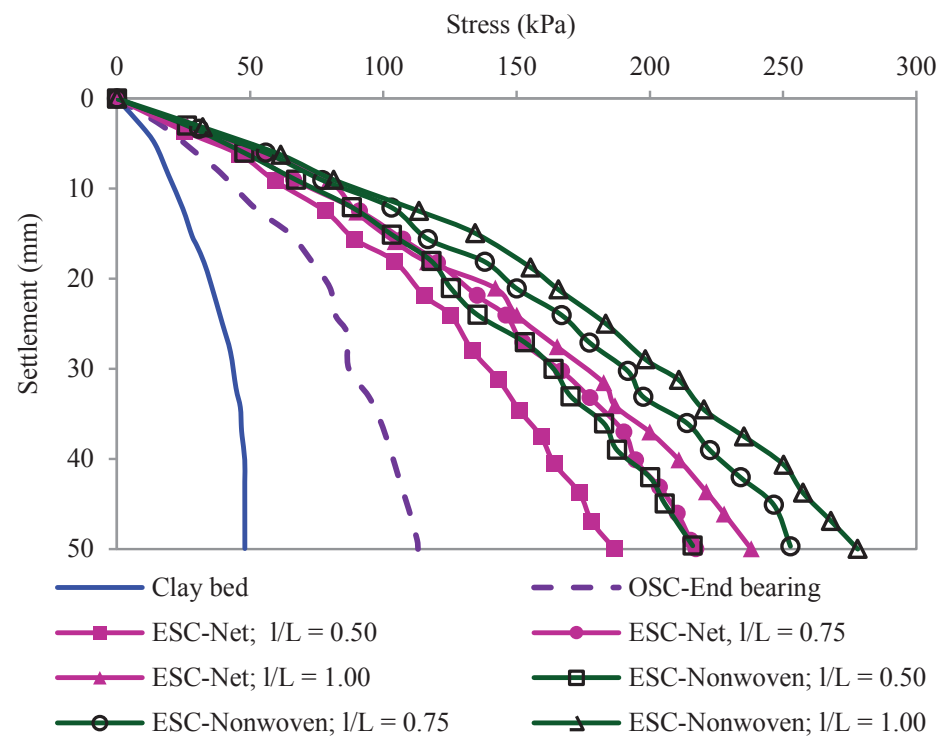

Fig. 8. Comparison of stress-settlement curve for OSC and ESCs (Net and Non-woven geotextile) for different $l / L$ ratios.

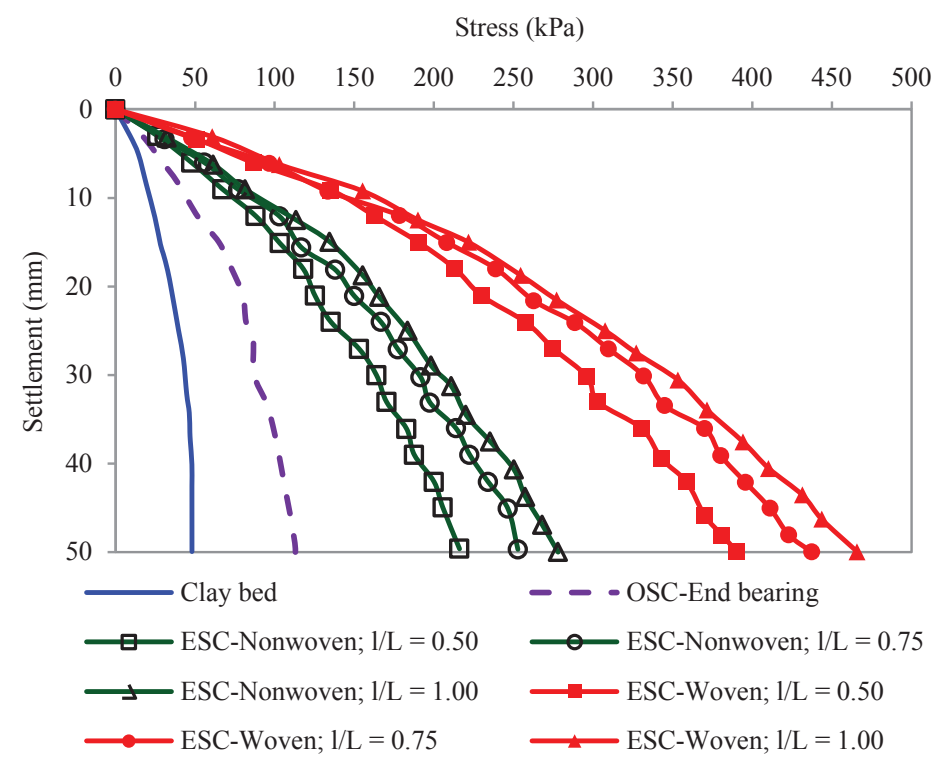

Fig. 9. Comparison of stress-settlement curve for OSC and ESCs (Non-woven and Woven geotextile) for different $l / L$ ratios. 


\subsection{EfFect of $L / H$ Ratio on Stress-Settlement Behaviour of OSCs and ESCs}

Model tests results for OSC in terms of stress and settlement for different column length for $50 \mathrm{~mm}$ diameter is shown in Fig. 10. The column with $L / H$ ratio of 1.00 (end bearing) exhibited rapid increase in the resistance with settlement, since resting on hard strata. However, the rate of increase of resistance decreases with settlement. Similar trend was observed for stone column of smaller length $(L / H=0.50$ and $L / H=0.75)$.

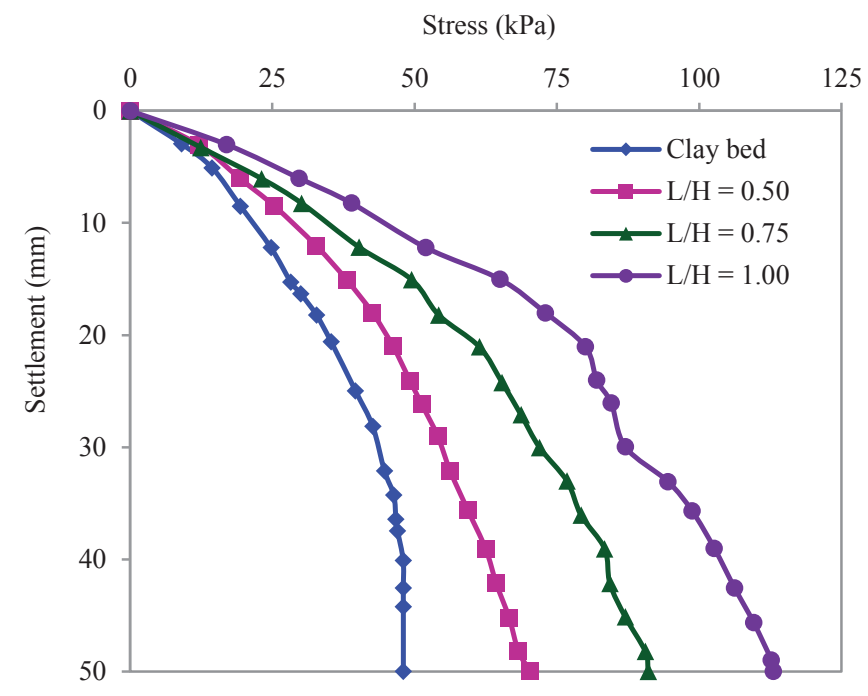

Fig. 10. Stress-settlement behvaiour of OSCs for different $L / H$ ratios.

Figure 11 and 12 show the comparison of the stress-settlement response of the ESCs with net \& non-woven geotextile encapsulation and non-woven geotextile \& woven geotextile encapsulation respectively for different $L / H$ ratio. The shape of the stress-settlement curves is identical and independent of the length of the column, but the load increased with the $L / H$ ratio of the stone column. It is seen that for all encapsulation material, column with $L / H$ ratio of 1.00 provide much higher resistance than column with $L / H=0.50$. The capacity of woven encapsulated stone column with $\mathrm{L} / \mathrm{H}$ ratio of 0.50 is 2.13 times and 1.18 times higher than stone column encapsulated with net and non-woven geotextile with $L / H=0.50$. 


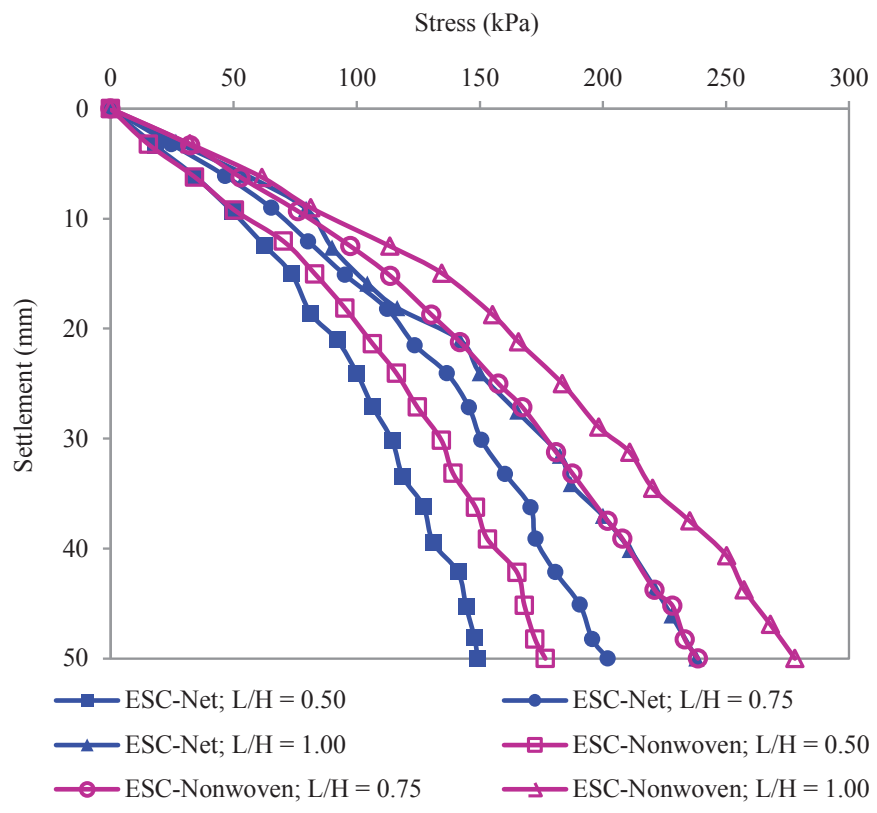

Fig. 11. Stress-settlement behvaiour of ESCs (Net and Non-woven geotextile) for different $L / H$ ratios.

Stress $(\mathrm{kPa})$



Fig. 12. Stress-settlement behvaiour of ESCs (Non-woven and woven geotextile) for different $L / H$ ratios. 


\subsection{EFFeCt of DiAMETER on STRESS-SETTLEMENT BEHAVIOUR OF OSCs AND ESCs}

The effect of column diameter on the stress at $50 \mathrm{~mm}$ settlement for different OSCs with different $L / H$ ratio is shown in Figure 13. It can be seen form figure that the stress-settlement responses of the OSC of different diameters are almost the same for a given $L / H$ ratio. Figure 14 shows the effect of column diameter on the stress at $50 \mathrm{~mm}$

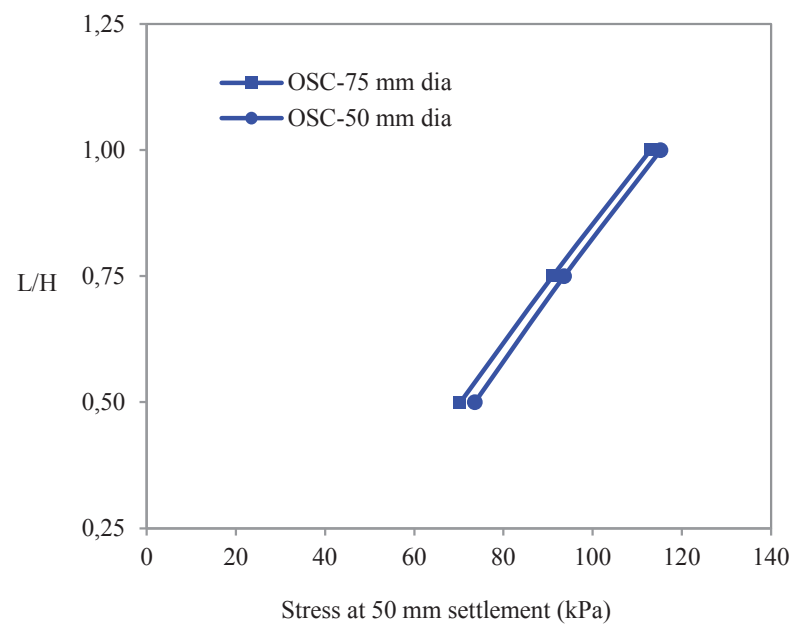

Fig. 13. Effect of diameter on stress-settlement behvaiour of OSCs.



Fig. 14. Effect of diameter on stress-settlement behvaiour stone column encapsulated with woven geotextile for different $L / H$ and $l / L$ ratios. 
settlement for stone column encapsulated with woven geotextile for different $l / L$ and $L / H$ ratio. It can be seen that, the stress developed in the ESCs of different $l / L$ and $\mathrm{L} / \mathrm{H}$ ratio decreased with an increase in the diameter of the column. For an increase in the column diameter from $50 \mathrm{~mm}$ to $75 \mathrm{~mm}$, the stress of the stone column decrease by approximately $42 \%, 49 \%$ and $52 \%$ for $L / H$ ratio of $0.50,0.75$ and 1.00 respectively. The stresses at $50 \mathrm{~mm}$ settlement for $50 \mathrm{~mm}$ diameter column are $390.53 \mathrm{kPa}, 437.46 \mathrm{kPa}$ and $465.98 \mathrm{kPa}$ for $l / L$ ratios of $0.50,0.75$ and 1.00 respectively. The relevant stresses for $75 \mathrm{~mm}$ diameter are $198.15 \mathrm{kPa}, 230.45 \mathrm{kPa}$ and $269.67 \mathrm{kPa}$ respectively. The decreases in stress are of the order of $49 \%, 47 \%$ and $42 \%$ respectively that of the $75 \mathrm{~mm}$ diameter column.

\subsection{RADIAL DEFORMATION OF STONE COLUMN}

After completion of each test, the shape of the stone column was established by carefully removing the sand and filling the hole with a paste of plaster of paris. This material is in powder form and when mixed with water, it reforms into a thick paste, which cannot penetrate in clay due to high viscosity and eventually gets hardened into a solid within a day. After the paste gets hardened, the surrounding clay was removed. FEM analysis is also carried out to examine the radial deformation developed along the length of the stone column at a vertical settlement of $50 \mathrm{~mm}$ and to compare the deformed shape of the stone column observed in the laboratory model tests.

\subsubsection{Effect of Encapsulation Material on Radial Deformation of Stone Column}

Encapsulating the stone column with suitable geosynthetic, the stone columns were confined, and the radial deformation had significantly reduced. The comparison of radial deformation of OSC and ESCs with different encapsulation material is shown in Fig. 15 for $50 \mathrm{~mm}$ diameter end bearing stone column at a vertical settlement of $50 \mathrm{~mm}$. The maximum radial deformation is observed to decrease due to the effects of lateral confinement provided by encapsulation material. The maximum radial deformation of OSC is about $9.39 \mathrm{~mm}$ at top portion of column, which is reduced to $2.82 \mathrm{~mm}$ by encapsulation with woven geotextile. In ESCs, radial deformation zone extended upto a depth of $150 \mathrm{~mm}$, in ESCs it is about $250 \mathrm{~mm}$. This phenomenon may be due to mobilization of axial stress to lower depth as compared to OSC. The corresponding deformed shapes of the columns as observed after exhumation are shown in Fig. 16. 


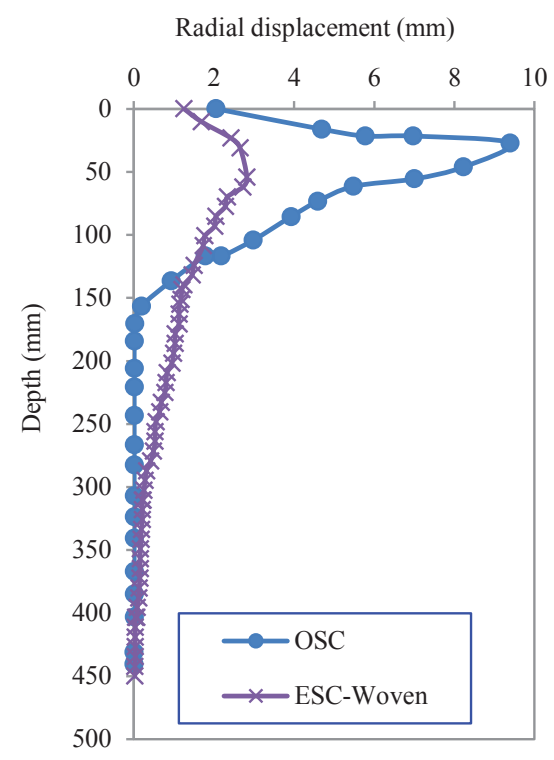

Fig. 15. Radial deformation comparison of OSC and ESCs.



OSC

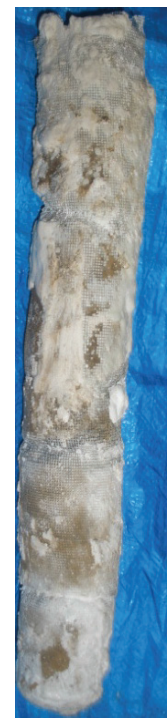

ESC-Net

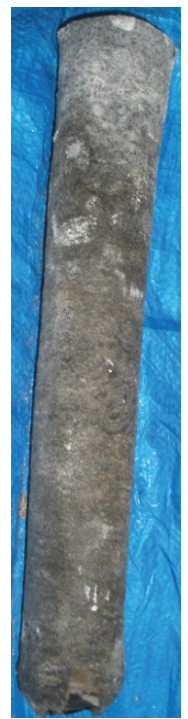

ESC-Non-woven

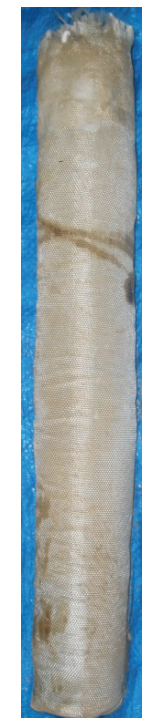

ESC-Woven

Fig. 16. Deformed shapes of $50 \mathrm{~mm}$ diameter OSC and ESCs. 


\subsubsection{Effect of Diameter on Radial Deformation of Stone Column}

Radial deformation of varying-diameter ESCs are presented in Fig. 17 for end bearing column at a vertical settlement of $50 \mathrm{~mm}$. As shown, the radial deformation increased

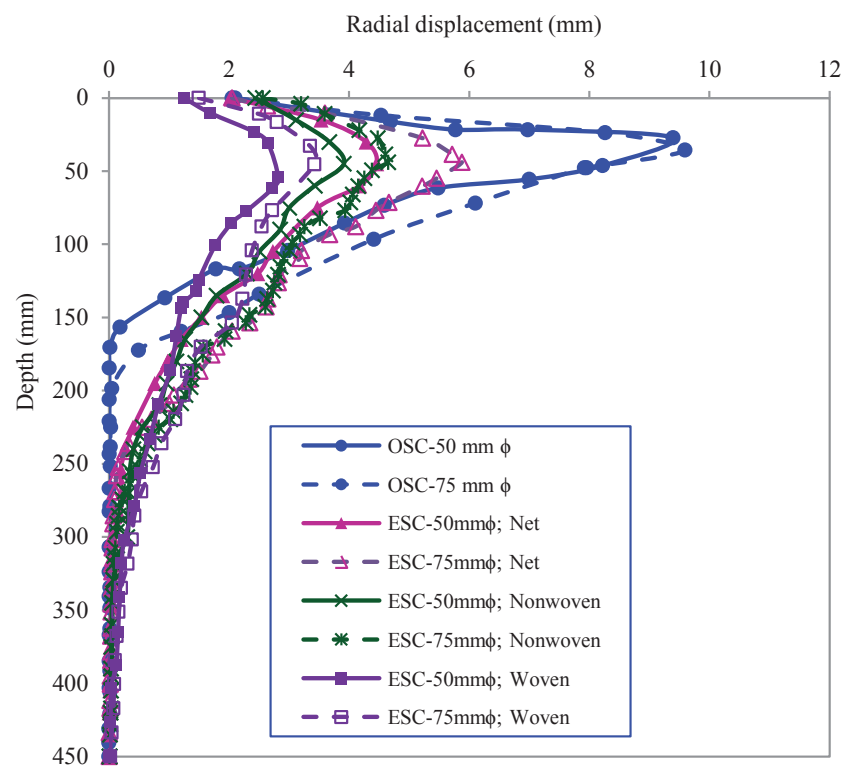

Fig. 17. Radial deformation comparison of OSCs and ESCs for different diameter of stone column.

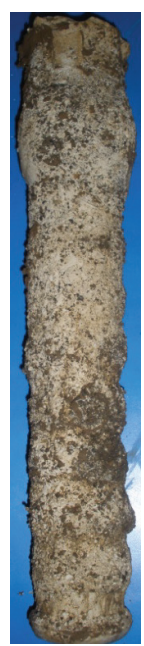

OSC

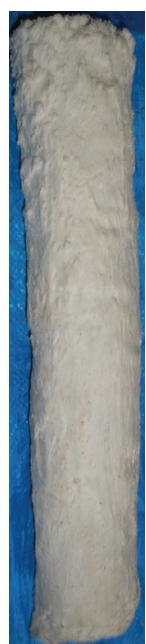

ESC-Net

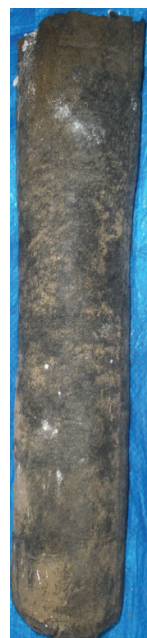

ESC-Non-woven

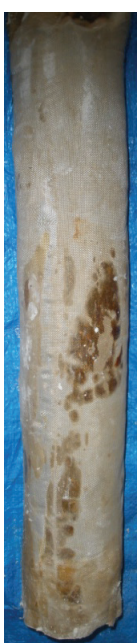

ESC-Woven

Fig. 18. Deformed shapes of $75 \mathrm{~mm}$ diameter OSC and ESCs. 
with the diameter of the column. This increase was noticeable up to depths of 200 to $250 \mathrm{~mm}$ for ESCs, after this, the relative radial deformation of the columns was not significantly affected by the column diameter. Whereas for OSCs effect of diameter on radial deformation is observed up to a depth of $175 \mathrm{~mm}$. Figure 18 shows the deformed shapes of $75 \mathrm{~mm}$ diameter OSC and ESCs after exhumation.

\subsubsection{Effect of $l / L$ ratios on Radial Deformation of ESCs}

Radial deformation of partially encapsulated columns having $l / L=0.50, l / L=0.75$ are presented together with a fully encapsulated stone column in Fig. 19, for a vertical settlement of $50 \mathrm{~mm}$. This graph is presented for columns encapsulated with woven geotextile. From this figure, it can be seen that maximum radial deformation for stone column with $L / H$ ratio of 0.75 and 1.00 is occurred at the top portion of stone column. Whereas for $L / H=0.50$, maximum radial deformation is at the junction of encapsulated and unencapsulated portion of stone column. This may be due to transmission of vertical load to the bottom of encapsulated portion. The deformed shapes of ESCs for different $l / L$ ratios are shown in Fig. 20.

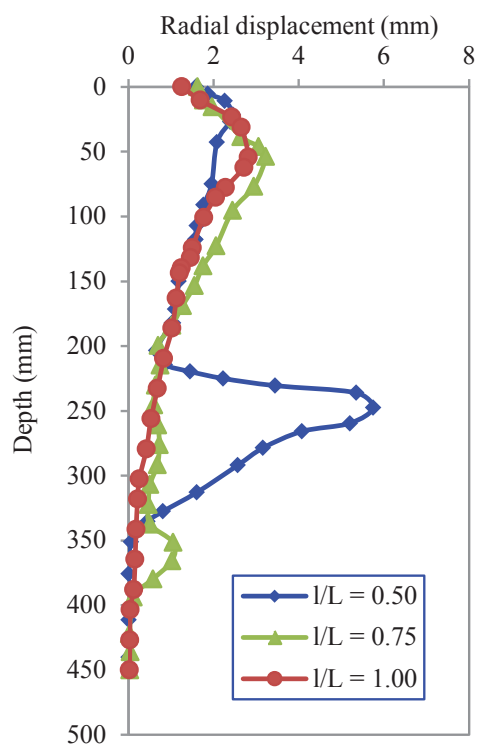

Fig. 19. Radial deformation comparison of ESCs for different $l / L$ ratios. 


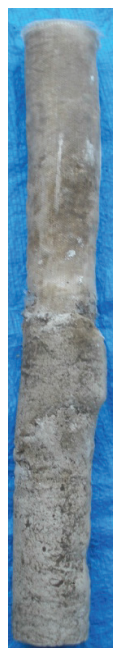

$l / L=0.50$

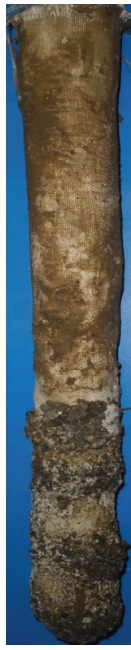

$l / L=0.75$



$l / L=1.00$

Fig. 20. Deformed shapes of ESCs for different $l / L$ ratios.

4.5.4. Effect of $L / H$ ratio on Radial Deformation of ESCs

Radial deformation of ESCs for $L / H$ ratio of $0.50,0.75$ and with end bearing column is presented in Fig. 21 for stone column encapsulated with woven geotextile. For $L / H$ ratio of 0.50 and 0.75 , depending on the resistance of the clay, certain amount of radial defor-

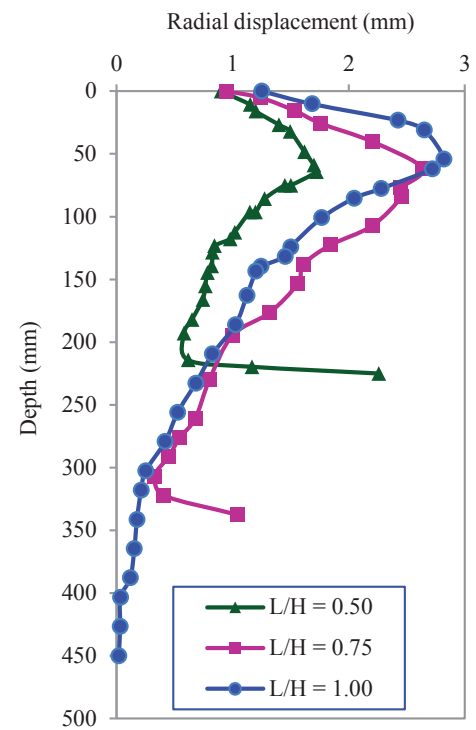

Fig. 21. Radial Deformation comparison of ESCs for different $L / H$ ratios. 
mation at the bottom of the stone column is also observed. Typical deformed shapes of ESCs for different $L / H$ ratios are shown in Fig. 22.

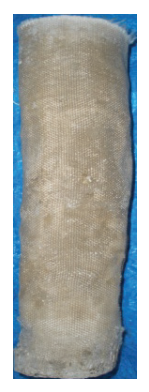

$L / H=0.50$



$L / H=0.75$



$L / H=1.00$

Fig. 22. Deformed shapes of ESCs for different $L / H$ ratios.

\section{Conclusions}

Investigations were carried out on OSCs and ESCs to examine the effect of stiffness of encapsulation material, column diameter, encapsulation length and length of column on load deformation behaviour and radial deformation of stone column. Based on the present study, following conclusions are drawn.

1. The load carrying capacity of stone column increases by encapsulation with suitable geosynthetic whether the column is end bearing, floating or partially encapsulated.

2. The stiffness of encapsulation material has a great influence on load carrying capacity of ESCs.

3. Column diameter have a negligible effect on stress of OSCs where as stress on ESCs increases with decreasing column diameter because of mobilization of higher confining stresses in a smaller diameter ESCs.

4. The encapsulation upto top portion of the stone column where radial deformation takes place can substantially increases its load carrying capacity.

5. The stress-settlement response of stone column increases with increasing $L / H$ and $l / L$ ratios. 
6. Fully encapsulated floating column with $\mathrm{L} / \mathrm{H}$ ratio of 0.75 have almost the same stress as that of the fully encapsulated end-bearing column.

7. The load carrying capacity of stone column having partial encapsulation over $75 \%$ length of column and fully encapsulated floating column of length equal to $75 \%$ of length of clay bed is close to that of fully encapsulated end bearing column.

8. The maximum radial deformation of ESC is much less than that of an OSC for the same vertical settlement. This may be due the fact that encapsulation allows more amount of loads transmitted to lower depths, which causes the radial deformations to be more evenly distributed over the length of the column than OSC.

\section{REFERENCES}

1. D. ALEXIEW, D. BROKEMPER, S. LOTHSPEICH, Geotextile Encased Columns (GEC): Load Capacity, Geotextile Selection and Pre-design Graphs, Geo-Frontiers, ASCE Geotechnical Special Publication, 497-510, Austin, USA 2005.

2. H. G. KEMPFERT, P. WALLIS, Geokunststoffummantelte Sandsäulen-einneues Gründungsverfahren im Verkehrswegebau, Geotechnik Sonderheft zur 5-Informations und Vortragsveranstaltung über Kunststoffe in der Geotechnik, 411-416, München, Germany 1997. (in German)

3. H. G. KEMPFERT, W. MÖBIUS, P. WALLIS, M. RAITHEL, M. GEDUHN, R. G. MCCLINTON, Reclaiming Land with Geotextile-Encased Columns, Geotechnical Fabrics Report, 8, 34-39, 2002.

4. U. TRUNK, G. HEERTEN, A. PAUL, E. REUTER, Geogrid Wrapped Vibro Stone Columns, Third European Geosynthetics Conference, Geotechnical Engineering with Geosynthetics, 289-294, Munich, Germany, 2004.

5. L. G. DE MELlO, M. MONDOLFO, F. MONTEZ, C. N. TSUKAHARA, W. BILFINGER, First Use of Geosynthetic Encased Sand Columns in South America, First Pan-American Geosynthetics Conference, 1323-1341, Cancun, Mexico 2008.

6. G. ARAUJO, M. PALMEIRA, R. CUNHA, Behaviour of Geosynthetic-Encased Granular Columns in Porous Collapsible soil, Geosynthetics International, 16, 6, 433-451, 2009.

7. T. AYADAT, A. M. HANNA Encapsulated Stone Columns as A Soil Improvement Technique for Collapsible Soil, Ground Improvement, 9, 4, 137-147, 2005.

8. C. DI PRISCO, A. GALLI, E. CANTARELLI, D. BONGIORNO, Georeinforced Sand Columns: Small Scale Experimental Tests and Theoretical Modeling, $8^{\text {th }}$ Int. Conf. on Geosynthetics, 1685-1688, The Netherlands, 2006.

9. S. N. MALARVIZHI, K. ILAMPARUTHI, Comparative Study on the Behavior of Encased stone column and Conventional Stone Column, Soils and Foundations, 47, 5, 875-885, 2007.

10. S. MURUGESAN, K. RAJAGOPAL, Model Tests on Geosynthetic Encased Stone Columns, Geosynthetic International, 14, 6, 346-354, 2007.

11. J. GNIEL, A. BOUAZZA, Improvement of Soft Soils Using Geogrid Encased Stone Columns, Geotextile and Geomembrane, 27, 3, 167-175, 2009.

12. C. S. WU, Y. S. HONG, Laboratory Tests on Geosynthetic Encapsulated Sand Columns, Geotextile and Geomembrane, 27, 2, 107-120, 2009.

13. M. KHABBAZIAN, V. N. KALIAKIN, C. L. MEEHAN, Numerical Study of Geosynthetic Encasement on The Behaviour of Granular Columns, Geosynthetics International, 17, 3, 132-142, 2010.

14. S. R. LO, R. ZHANG, J. MAK, Geosynthetic-Encased Stone Columns in Soft Clay: A Numerical Study, Geotextiles and Geomembranes, 28, 3, 292-302, 2010.

15. M. MURUGESAN, K. RAJAGOPAL, Geosynthetic-Encased Stone Columns: Numerical Evaluation, Geotextiles and Geomembranes, 24, 6, 349-358, 2006. 
16. B. PULKO, B. MAJES, L. LOGAR, Geosynthetic-Encased Stone Columns: Analytical Calculation Model, Geotextiles and Geomembranes, 29, 1, 29-39, 2011.

17. C. YOO, S. B. KIM, Numerical Modeling of Geosynthetic Encased Stone Column-Reinforced Ground, Geosynthetics International, 16, No. 3, 116-126, 2009.

18. Y. ZHANG, D. CHAN, Y. WANG, Consolidation of Composite Foundation Improved by GeosyntheticEncased Stone Columns, Geotextiles and Geomembranes, 32, 10-17, 2012.

19. M. RAITHEL, H. G. KEMPFERT, Calculation Models for Dam Foundations With Geotextile-Coated Sand Columns, GeoEngineering, 347, Melbourne, Australia 2000.

20. C. WU, Y. HONG, H. LIN, Axial Stress-Strain Relation of Encapsulated Granular Column, Computers and Geotechnics, 36, 226-240, 2009.

21. J. E. BOWLES, Foundation analysis and design, $5^{\text {th }}$ Ed., McGraw- Hill International Editions, Singapore 1988.

22. ASTM D4595, Standard Test Method for Tensile Properties of Geotextiles by Wide-Width Strip Method, ASTM International, West Conshohocken, PA. 1986.

23. R. B. BRINKGREVE AND P. A. VERMEER, PLAXIS 3D-Finite Element Code for Soil and Rocks Analysis, Balkema, Rotterdam, The Netherlands, 2012.

24. A. P. AMBILY, S. R. GANDHI, Behavior of Stone Columns Based on Experimental and FEM Analysis, Journal of Geotechnical and Geoenvironmental Engineering, 133, 4, 405-415, 2007.

25. V. MUSTAFA, A. MUSTAFA, S. BANU IKIZLER, C. UMIT CALIK, Experimental and Numerical Investigation of Slope Stabilization by Stone Columns, Natural Hazards, 64, 797-820, 2012.

Received: 12.03 .2013

Revised: 20.08.2013 